\title{
Sex determination in the Hymenoptera: a review of models and evidence
}

\author{
JAMES M. COOK \\ Department of Genetics \& Human Variation, La Trobe University, Bundoora 3083, Victoria, Australia
}

\begin{abstract}
The haploid males and diploid females of Hymenoptera have all chromosomes in the same proportions. This rules out most familiar sex-determining mechanisms, which rely on dosage differences at sex determination loci. Two types of model - genic balance and complementary sex determination (CSD) - have been invoked for Hymenoptera. Experimental studies provide no good evidence for genic balance models, which are contradicted by the detection of diploid males in 33 disparate species. Furthermore, recent advances have shown that sex determination in the beststudied diploid animals does not depend on genic balance, removing the original justification for hymenopteran genic balance models. Instead, several Hymenoptera have single-locus CSD. In this system, sex locus heterozyotes are female while homozygotes and hemizygotes are male. Singlelocus CSD does not apply to several inbreeding species and this probably reflects selection against the regular production of diploid males, which are sterile. A multilocus CSD model, in which heterozygosity at any one of several sex loci leads to female development has also been proposed. To date, multilocus CSD has not been demonstrated but several biases against its detection must be considered. CSD can apply to thelytokous races as long as the cytogenetic mechanism permits retention of sex locus heterozygosity. However, some thelytokous races clearly do not have CSD. The distribution of species with and without CSD suggests that this form of sex determination may be ancestral in the Hymenoptera. However, phylogenetic analyses are hindered by the lack of data from several superfamilies and the fact that the internal phylogeny of the Hymenoptera remains controversial.
\end{abstract}

Keywords: arrhenotoky, diploid male, haplodiploidy, Hymenoptera, sex determination, thelytoky.

\section{Introduction}

The extraordinary variety of sex-determining mechanisms was reviewed by Bull (1983). In the two beststudied animal species, the fruitfly Drosophila melanogaster and the nematode Caenorhabditis elegans, sex is determined by the ratio of feminizing $\mathrm{X}$ chromosomes to masculinizing autosomes (Bridges, 1921; Madi \& Herman, 1970). However, the superficial organizational similarity of sex determination in $D$. melanogaster and $C$. elegans is not matched by the underlying genetic systems. For example, the X:A ratios that lead to intersexuality are different (Bridges, 1921; Madi \& Herman, 1970) and it appears that the two species differ in both the number and form of the feminizing $\mathrm{X}$-chromosome numerator elements (Cline, 1988; Hodgkin, 1990). In contrast with Droso-

Correspondence: Dr James M. Cook, Dept. of Biology, Imperial College, Silwood Park, Ascot, Berks. U.K. phila and Caenorhabditis, sex determination in mammals depends on the presence/absence of the male-determining $\mathrm{Y}$ chromosome, regardless of the number of $\mathrm{X}$ chromosomes or autosomes (Ohno, 1979). In general, sex-determining mechanisms appear not to be highly conserved in evolution (Bull, 1983), although certain general organizational features, such as $\mathrm{X}: \mathrm{A}$ ratios, may arise repeatedly from different molecular systems (Hodgkin, 1990).

The common mode of reproduction in the Hymenoptera is arrhenotoky. Haploid males arise from unfertilized eggs, receiving a single set of maternal chromosomes while diploid females arise from fertilized eggs and receive both maternal and paternal chromosomes. Thelytokous species, consisting entirely of females, also occur but are less common (Slobodchikoff \& Daly, 1971; Luck et al., 1992). The patchy taxonomic distribution of thelytoky is consistent with several independent evolutionary origins from ancestral arrhenotokous species (White, 1973; Bull, 1983). 
Early reports of heteromorphic chromosome pairs in some Hymenoptera have not been supported by further studies (White, 1973) and all chromosomes occur in the same proportions in both sexes (Crozier, 1971). This precludes most familiar diplodiploid sexdetermining mechanisms, which rely on interlocus dosage differences, such as presence/absence of a Y chromosome or X:A ratios.

There are two current sets of models for hymenopteran sex determination: complementary sex determination (CSD) and genic balance. Under single-locus CSD (Whiting, 1939, 1943), sex is determined by multiple alleles at a single locus. Sex locus heterozygotes are female while hemizygous and homozygous individuals develop as haploid and diploid males respectively. CSD stands out as the only documented case of sex factors (genetic elements that form the hereditary basis of sex - Bull, 1983) without particular sex tendencies (i.e. male or female tendencies Bull, 1983). A related model is multilocus CSD (Snell, 1935; Crozier, 1971), where two or more loci contribute to sex determination. Heterozygosity at one or more of these loci leads to female development.

Genic balance models (Cunha \& Kerr, 1957; Kerr, 1974a, b; Chaud-Netto, 1975) attribute sex determination to female-determining factors with cumulative effects and male-determining factors with no or only slightly cumulative effects. In haploids the male tendency predominates while in diploids, female but not male tendencies are cumulative and the balance becomes female. Another possible sex-determining mechanism is the ratio of nuclear to cytoplasmic products (Crozier, 1971) but this has received little attention and no empirical support.

In this paper the justifications, predictions and evidence for genic balance and CSD models are examined critically. Despite several experimental studies, there is no good evidence for genic balance models. Furthermore, their original justification as part of a wider scheme of sex determination is weakened considerably by recent molecular studies of Drosophila and Caenorhabditis. Single-locus CSD is found in several, disparate species of Hymenoptera but is not ubiquitous. There is no good evidence for multilocus CSD but it is not yet clear whether this reflects its absence or the difficulties of testing the model. Sex determination in thelytokous races is considered, with emphasis on the importance of different cytogenetic mechanisms. The important recent discoveries of cytoplasmic sex ratio distorters and parthenogenesis bacteria are also briefly discussed. The ancestry of single-locus CSD is considered and the taxonomic distribution of species with and without single-locus CSD is used to speculate on phylogenetic processes. Finally, some important areas for future research are identified.

\section{Models and their predictions}

\section{Genic balance}

Although the notion of genic balance was formulated from studies of Drosophila melanogaster, a diplodiploid species, Bridges (1939, p. 58) considered that it should also apply to the haplodiploid Hymenoptera. Male haploidy does not lend itself to genic balance explanations since all chromosomes occur in the same proportions in both sexes (Crozier, 1971). However, Cunha \& Kerr (1957) proposed that sex was determined by a series of compensated (non-cumulative) maleness genes $(\mathrm{m})$ and a series of dose-dependent (cumulative) femaleness genes (f). The effects of $m$ genes are the same in haploids and diploids and can be represented as $M$ while the effects of $f$ genes are $F$ in haploids but $2 \mathrm{~F}$ in diploids. Sex is then determined by the relation $2 \mathrm{~F}>\mathrm{M}>\mathrm{F}$, such that diploids are always female and haploids always male. In response to some empirical results, Kerr (1974b) later suggested that m genes might be slightly cumulative but less so than $\mathrm{f}$ genes. Under these models only haploids are male; diploids, triploids, etc. will always be female.

When Cunha \& Kerr (1957) proposed their model, diploid males were known only in the genus Bracon, which they regarded as an exception. Cunha \& Kerr (1957) argued that Bracon represents a special case of genic balance where a major feminizing locus, which they referred to as the $\mathrm{x}$ locus, has lost its cumulative effect except when heterozygous. Diploid males might then be expected to show some feminization relative to haploid males, due to the residual effects of minor $f$ loci. Kerr \& Neilsen (1967) further proposed that, in other species, $\mathrm{x}$ locus homozygotes might be males, intersexes or females, depending on the magnitude of the $\mathrm{x}$ locus sex tendency. However, the existence of diploid males in several, disparate species of Hymenoptera poses a serious problem for the hypothesis that these cases arose from a genic balance system. The argument requires that mutations leading to the production of sterile diploid males have arisen and become fixed on several independent occasions.

Empirical studies of genic balance are considered in the section 'Experimental studies of genic balance'. First, however, the current standing of genic balance models in general is considered. Bridges (1916, 1922, 1939) developed a theory of genic balance to account for the action of genes in both sex determination and sex development. Bull (1983, p. 49) noted that it is difficult to ascertain exactly what was 
meant by genic balance or whether Bridges intended some of his ideas to be restricted to Drosophila. However, genic balance encompasses two distinct ideas: (i) sex differentiation is influenced by many genes; (ii) these same genes are responsible for sex determination (the inheritance of sex) via the balance of their sex tendencies (Bridges, 1939, p. 42). Bridges' first suggestion is widely accepted and supported by molecular studies in D. melanogaster (Baker \& Belotte, 1983; Hodgkin, 1990) and C. elegans (Hodgkin, 1990). However, the same molecular studies have shown that the genes responsible for sex differentiation are distinct from those elements that determine sex in the zygote, as first suggested by Sturtevant (1921). Furthermore, evidence from Drosophila (Cline, 1988) and mammals (Ohno, 1979) support Muller's (1932) prediction that sex determination is likely to depend on a few key regulatory genes. In addition, Baker \& Belotte (1983) and Bull (1983, p. 51) have pointed out that Bridges' equation of the genes responsible for sex determination with those that cause sex differentiation depends largely on his interpretation that $D$. melanogaster with unusual X:A ratios are supersexes, yet there appears to be no observational basis for this conclusion. The interpretation of gender in triploid animals is also complicated by dosage compensation effects (Hodgkin, 1990). In conclusion, the supercedure of genic balance ideas for diplodiploid species removes the earlier impetus to fit hymenopteran sex determination into a wider scheme of genic balance, as originally intended by Cunha \& Kerr (1957).

\section{Single-locus CSD}

Whiting $(1939,1943)$ proposed a model of single locus complementary sex determination (CSD) to explain the results of detailed studies of sex determination in the parasitoid wasp Bracon hebetor. Under single-locus CSD, sex is determined by multiple alleles at a single locus. Individuals are female if they carry two different alleles (heterozygotes) and male if they carry one (hemizygotes) or more (homozygotes) copies of the same allele. Thus haploids are male $\left(\mathrm{A}_{i}\right)$ but diploids may be male $\left(\mathrm{A}_{i} \mathrm{~A}_{i}\right)$ or female $\left(\mathrm{A}_{i} \mathrm{~A}_{i}\right)$. By extension, triploids are predicted to be male if they have three copies of the same allele but female if they have at least two different alleles.

Single-locus CSD yields several testable predictions. A simple qualitative prediction is that inbreeding should increase diploid male production because it increases homozygosity. The use of controlled matings between relatives permits quantitative predictions. For example, broods with 0 per cent and 50 per cent diploid males should be equally common following sib- matings. As another example, the diploid offspring of any mother/son mating should be 50 per cent male (Cook, 1993). Furthermore, any matings between siblings in a brood that contains diploid males should also produce diploid males. Another approach is to use genetic markers to demonstrate male diploidy and paternal inheritance. However, genetic markers are known for only a few Hymenoptera.

\section{Multilocus CSD}

Snell (1935) hypothesized that sex in B. hebetor was determined by several loci, each with two alleles, so that an individual heterozygous at any of these loci is female while homozygotes and hemizygotes are male. Although Whiting (1943) subsequently showed that $B$. hebetor has only one sex locus, single-locus CSD is not ubiquitous since many parasitoid species inbreed without producing high levels of diploid males. Since diploid males are sterile in all cases investigated, singlelocus CSD is inherently disadvantageous in inbreeding species. However, Crozier $(1971,1977)$ argued that diploid male production could remain low under multilocus CSD as long as occasional outcrosses occurred to restore heterozygosity. Crozier's (1971) multilocus model relaxes Snell's (1935) assumption of two alleles per locus and proposes a general model involving $n$ loci, each with $k$ alleles. As in the models of Whiting and Snell, diploids are female if one or more sex loci are heterozygous. It is then possible to regard both Whiting's (1943) single-locus model and Snell's (1935) multilocus, two allele model as special cases of Crozier's (1971) more general formulation. Crozier (1971) envisaged variation between species in the number of sex loci. However, he noted that the upper limit to $n$ would be relatively low since diploid male production decreases rapidly as $n$ increases and selection will not be strong enough to maintain heterozygosity at many loci, unless these genes have other effects that also show heterozygote advantage.

Under multilocus CSD, inbreeding leads to sterile diploid male production but more slowly than with single-locus CSD. Quantitative tests of multilocus CSD are essentially extensions of the inbreeding tests for single locus CSD for several generations (Cook, 1993). The number of generations of sib-mating required to cause diploid male production then provides an estimate of the number of sex loci. If an inbreeding programme is started with a mother/son mating, 10 subsequent generations of inbreeding should be sufficient to detect a system involving at least 15 independent loci (Cook, 1993). More generations would be required if a mother/son cross was not possible. As in single-locus CSD, triploids are expected to be male if 
homozygous at all sex loci and female if heterozygous at one or more of these loci.

\section{Experimental studies of genic balance}

The existence of diploid males in many disparate species of Hymenoptera (Table 1) contradicts the original model of Cunha \& Kerr (1957) and suggests that they are the rule rather than the exception. Attempts to provide empirical support for genic balance models have been restricted to measurements of the 'degree of sexuality' to test the prediction that diploid males are feminized due to residual effects of minor f genes. Kerr \& Neilsen (1967) argued that morphological features of honeybee diploid males were feminized relative to haploid males, suggesting residual effects of minor $f$

Table 1 Species of Hymenoptera in which diploid males have been detected. Method: cytology (C), allozymes (A), genetic markers $(\mathrm{G})$, morphology $(\mathrm{M})$, DNA fingerprinting $(\mathrm{F})$ and in response to inbreeding $(\mathrm{I})$

\begin{tabular}{|c|c|c|}
\hline Species & Method & References \\
\hline \multicolumn{3}{|l|}{ Sub-order Symphyta } \\
\hline \multicolumn{3}{|l|}{ Tenthredinoidea } \\
\hline Athalia rosae ruficornis & $\mathrm{C}, \mathrm{I}, \mathrm{M}$ & Naito \& Suzuki (1991) \\
\hline Neodiprion nigroscutum & $\mathrm{C}, \mathrm{I}, \mathrm{M}$ & Smith \& Wallace $(1971)$ \\
\hline$N$. pinetum & A? & Data cited in Stouthamer et al. (1992) \\
\hline \multicolumn{3}{|c|}{ Sub-order Apocrita infra-order Parasitica } \\
\hline \multicolumn{3}{|c|}{ Ichneumonoidea } \\
\hline Bathyplectes curculionis & A & Unruh et al. $(1984)$ \\
\hline Bracon brevicornis & $\mathrm{C}, \mathrm{I}, \mathrm{G}$ & Speicher \& Speicher $(1940)$ \\
\hline Bracon hebetor & $\mathrm{C}^{1}, \mathrm{I}^{2}, \mathrm{G}^{2}$ & Whiting \& Whiting $(1925)^{1}$, Whiting $(1943)^{2}$ \\
\hline Bracon serinopae & $\mathrm{C}, \mathrm{I}, \mathrm{G}$ & Clark \& Rubin (1961) \\
\hline Cotesia rubecula & A & Cited in Stouthamer et al. (1992) \\
\hline Diadromus pulchellus & $\mathrm{A}, \mathrm{C}$ & Hedderwick et al.(1985) \\
\hline Microplitis croceipes & A & Steiner \& Teig $(1989)$ \\
\hline \multicolumn{3}{|l|}{ Chalcidoidea } \\
\hline Nasonia vitripennis $\dagger$ & $\mathrm{C}$ & Whiting (1960) \\
\hline \multicolumn{3}{|l|}{ Cynipoidea } \\
\hline Diplolepis rosae $\dagger$ & $\mathrm{C}$ & Stille \& Dävring (1980) \\
\hline \multicolumn{3}{|c|}{ Sub-order Apocrita infra-order Aculeata } \\
\hline \multicolumn{3}{|c|}{ Apoidea } \\
\hline Apis cerana & $\mathrm{C}^{12}, \mathrm{I}^{1}$ & Woyke $(1979)^{\prime}$, Hoshiba et al. $(1981)^{2}$ \\
\hline Apis mellifera & $\mathrm{C}^{1}, \mathrm{I}^{2}, \mathrm{G}^{3}$ & Woyke $\left(1963^{1}, 1965^{3}\right)$, Mackensen $(1951)^{2}$ \\
\hline Augochlorella striata & $\mathrm{A}^{1}, \mathrm{~F}^{2}$ & Packer \& Owen $(1990)^{1}$, Mueller $(1993)^{2}$ \\
\hline Bombus atratus & $\mathrm{C}^{12}, \mathrm{I}^{12}$ & Garófalo $(1973)^{1}$, Garófalo \& Kerr $(1975)^{2}$ \\
\hline Lasioglossum zephyrum & A & Kukuk \& May $(1990)$ \\
\hline Melipona compressipes & $\mathrm{C}$ & $\operatorname{Kerr}(1987)$ \\
\hline Melipona quadrifasciata & C,I & Camargo (1979) \\
\hline Trigona quadrangula & $\mathrm{C}$ & Tarelho $(1973)$ \\
\hline \multicolumn{3}{|l|}{ Vespoidea (Vespidae) } \\
\hline Mischocytarrus immarginatus & A & Queller et al.(1992) \\
\hline Liostenogaster flavolineata & A & J. Strassmann (personal communication) \\
\hline \multicolumn{3}{|l|}{ Vespoidea (Formicidae) } \\
\hline Doronomyrmex kutteri & $\mathrm{C}$ & Fischer (1987) \\
\hline Epimyrma stumperi & $\mathrm{C}$ & Fischer $(1987)$ \\
\hline Formica aquilonia & A & Pamilo (in preparation) \\
\hline Formica pressilabris & A & Pamilo \& Rosengren (1984) \\
\hline Harpagoxenus sublaevis & $\mathrm{C}$ & Fischer $(1987)$ \\
\hline Lasius alienus & A & Pearson $(1983)$ \\
\hline Leptothorax muscorum* & $\mathrm{C}$ & Loiselle et al. $(1990)$ \\
\hline Pseudolasius nr. emeryi & $\mathrm{C}$ & Hung et al. $(1972)$ \\
\hline Rhytidoponera chalybaea & A & Ward $(1980)$ \\
\hline Rhytidoponera confusa & A & Ward $(1980)$ \\
\hline Solenopsis invicta & $C^{1}, A^{2}, G^{2}$ & Hung et al. $(1972)^{1}$, Hung \& Vinson $(1976)^{2}$ \\
\hline
\end{tabular}

*Leptothorax muscorum probably comprises four or more species (Loiselle et al., 1990). †Uniparental diploid males. 
loci. However, Chaud-Netto (1975), measured 22 morphological characters in different honeybee sex types and came to the opposite conclusion - diploid male characters were 'supermale', i.e. displaced beyond haploid males on the normal male-female axis. ChaudNetto (1975) argued that these results still supported genic balance as they could reflect partially cumulative effects of $\mathrm{m}$ genes. However, $\mathrm{m}$ genes should still be outweighed by fully-cumulative $\mathrm{f}$ genes, leading to feminization of diploid relative to haploid males (Crozier, 1971).

Woyke (1980) showed that diploid male measurements were greater than haploid male measurements for all but one of 10 somatic characters measured. An attractive, alternative explanation (Woyke, 1980) is that diploid male structures are generally larger than haploid male equivalents not because they are more or less masculinized but because their somatic cells have a higher level of polyploidy (Woyke \& Krol-Paluch, 1985; Woyke, 1986).

The study of 'degrees of sexuality' has provided no clear support for sex determination by genic balance models but it is interesting to note that parallels between these studies and early interpretations of supermales in D. melanogaster (see section on 'Genic balance').

\section{Evidence for CSD in arrhenotokous species}

Evidence for and against CSD models has two main sources. Explicit tests of model predictions are most informative but information can also be gleaned from allozyme studies and experiments involving inbreeding. The studies are divided here into those providing strong support for single-locus CSD (eight species), those that support CSD but do not resolve the number of loci (four species) and reports of diploid males not supported by further experiments (19 species). The molecular basis of CSD is also briefly considered.

There is no authenticated case of multilocus CSD but two biases against its detection argue against a premature disposal of the model. First, it has been tested rigorously in very few species and, secondly, results may suggest single-locus CSD because experiments are carried out on lines with little genetic diversity and any multilocus CSD system can collapse to a single-locus system if alleles become fixed at all but one locus (Cook, 1993). The common initiation of experimental stocks with very small numbers of wild-caught individuals increases the importance of this bias. For example, the stock of Neodiprion nigroscutum used by Smith \& Wallace (1971) had its origin in a single, wildcaught pair.

\section{Single-locus CSD}

Bracon hebetor. Biparental, diploid males were first demonstrated in the parasitoid wasp Bracon hebetor (=Habrobracon juglandis), using recessive genetic markers for eye colour and flightlessness (Whiting \& Whiting, 1925). Cytological studies failed to yield evidence for a sex chromosome (Torvik-Greb, 1935) and several theories were proposed to explain the occurrence of male diploids (reviewed in Whiting, 1943, 1945). P. W. Whiting and others conducted a series of detailed experiments, using a number of genetic markers including one (fused) that is linked to the sex locus, to demonstrate that single-locus CSD operates in $B$. hebetor. Diploid males are rare in nature for two reasons. First, there are at least nine sex alleles in B. hebetor (Whiting, 1943) and frequency-dependent selection maintains the alleles at approximately equal frequencies (Laidlaw et al., 1956), resulting in very few sex locus homozygotes. Secondly, the viability of diploid male larvae relative to female larvae is only 0 to 0.4 (Grosch, 1945; Petters \& Mettus, 1980). B. hebetor diploid males produce diploid sperm (TorvikGreb, 1935), which rarely achieve fertilization, probably because they do not penetrate the egg (MacBride, 1946). Bostian (1934) reported that only about 10 per cent of adult diploid males produce any (triploid) offspring.

Triploid females have been found in $B$. hebetor (Whiting, 1961) but triploid males have yet to be reported. While triploid males and females should occur in equal proportions amongst the offspring of a diploid female $\left(\mathrm{A}_{i} \mathrm{~A}_{j}\right)$ and her diploid sons $\left(\mathrm{A}_{i} \mathrm{~A}_{i}\right.$ or $\left.\mathrm{A}_{j} \mathrm{~A}_{j}\right)$, only triploid females would be expected from a mating between a diploid female $\left(\mathrm{A}_{i} \mathrm{~A}_{j}\right)$ and a diploid male homozygous for a different sex allele $\left(\mathrm{A}_{k} \mathrm{~A}_{k}\right)$. Whiting (1961) suggested that triploid males may have been missed in early studies but the expected lethality of male triploidy is a more likely explanation. Since diploid males have very low viability (probably due to increased susceptibility to desiccation as a result of increased cell size - Petters \& Mettus, 1980), male triploidy is probably effectively lethal. In contrast, diploid females have a high level of viability so triploid females should retain some, albeit reduced, viability.

Bracon brevicornis. Speicher \& Speicher (1940) detected diploid males in B. brevicornis and demonstrated single-locus CSD using two recessive wing mutants (rough and defective) and crossing homozygous mutant females to wild-type males. The viability of diploid males was 0.66 relative to females; considerably higher than in $B$. hebetor. 
Apis mellifera. Mackensen (1951) found that four out of eight sib-mated queens produced high-viability diploid broods (circa 95 per cent) while the other four produced low viability broods (circa 48 per cent). Daily counts of broods showed that mortality occurred at the early larval stage, suggesting that single-locus CSD applied and that diploid males were totally inviable. Woyke $(1962,1963)$ subsequently showed that diploid males were not totally inviable but workers remove the diploid male larvae from the brood within six hours of hatching. Using genetic markers, Woyke (1965) confirmed the biparental, diploid nature of the drones removed by workers. In another study, Woyke (1974) found that diploid drone testis size was not influenced by background homozygosity, supporting the notion that sex is determined by a single locus.

Apis cerana. Diploid males have been detected cytologically in $A$. cerana indica (Woyke, 1979) and $A$. cerana japonica (Hoshiba et al., 1981). In contrast to $A$. mellifera, diploid drones are not cannibalized immediately on hatching, but are mostly eaten at the age of 1 day (Woyke, 1986). Woyke (1979) found that diploid drones comprised 27 per cent of the brood of $A$. cerana indica queens that had been artificially inseminated with sperm from several drones. Hoshiba et al. (1981) reported 27 diploid males amongst 105 individuals reared from the diploid brood ( 26 per cent) of a naturally sib-mated $A$. cerana japonica queen. Under single-locus CSD where the queen mates with several brothers, 25 per cent of the diploid brood is expected to be male.

Athalia rosae ruficornis. Naito \& Suzuki (1991) contrasted the offspring sex ratios of sib-mated and outcrossed broods of this sawfly and showed that half of the former produce a 1:1 ratio of diploid males to females in comparison to none of the latter. Further matings between haploid males and females from families with diploid males yielded the same 1:1 ratio. These results are in good agreement with the predictions of single-locus CSD.

Twenty-eight broods were obtained from crosses between diploid males and normal females. Five of these broods produced only haploid males, 16 produced haploid males and triploid females and seven produced haploid males, triploid females and triploid males. This was the first demonstration of triploid males as predicted by CSD models. The brood mortality and composition data suggest that triploid males are generally less viable than triploid females and that, in both sexes, some sex allele combinations are more viable than others.
Diadromus pulchellus. Hedderwick et al. (1985) detected heterozygous males of this ichneumonoid wasp in an allozyme study and demonstrated cytologically that they were diploid. Subsequently, Periquet $e t$ al. (1993) conducted breeding experiments in which diploid males were distinguishable as either allozyme or body colour heterozygotes and the data were consistent with single-locus but not two-locus CSD.

Augochlorella striata. Parker \& Owen (1990) detected a single heterozygous male during an allozyme study of this ground-nesting sweat bee. Subsequently, Mueller (1993) obtained DNA fingerprints of all individuals from 24 A. striata colonies. Diploid males were detected in only one colony, where the replacement queen had sib-mated. Six out of eight subsequent diploid offspring were male. Using the binomial theorem, the probability of six or more diploid males from eight diploid offspring is 0.1445 under singlelocus CSD but less than 0.0006 under two-locus CSD.

Melipona quadrifasciata. Camargo (1979) reported cytologically verified diploid males in $M$. quadrifasciata after 1-2 generations of sib-mating. In three of the five colonies to produce diploid males, the ratio of females:diploid males did not differ significantly from $1: 1$, as predicted by single-locus CSD. However, in the other two colonies the female to diploid male ratio was about 5:3. Further support for single-locus CSD comes from aunt/nephew matings: two out of four crosses between haploid sons and sisters of diploid male producing queens also led to diploid male production.

In one of the two colonies with reduced diploid male production there were 134 diploid males and 195 females with only 3 per cent mortality. Even if all mortality was due to diploid males, the observed sex ratio of diploids is still significantly different from $1: 1$ $\left(\chi^{2}=7.67\right.$, d.f. $\left.=1, P<0.05\right)$. The data could indicate multilocus CSD but results from other colonies and matings support the single locus case. Instead, multiple insemination is probably the explanation. Although Melipona queens normally mate only once, mating was not controlled in the experiments.

\section{CSD with one or a few loci}

Neodiprion nigroscutum. In the fourth generation of a culture started from a single, wild-caught pair of sawflies, Smith \& Wallace (1971) noted a bimodal distribution of male pupal weight. Cytological study revealed the existence of haploid and diploid males, with the latter, on average, 20-30 per cent heavier. Although the heaviest individuals were always diploid, the two weight distributions overlapped to some extent. Only 
one of the 150 diploid males tested produced offspring. These were three triploid females.

According to Smith \& Wallace (1981), three types of broods were produced in their cultures with 0,30 and 50 per cent of diploids male. Broods with 0 per cent diploid males were probably three-allele crosses and those with 50 per cent two-allele crosses. Those with 30 per cent pose a problem. The data suggest no significant difference in mortality between brood types, ruling out differential mortality by genotype as an explanation (contra Kerr, 1974a). Smith \& Wallace (1971) favoured a single locus model while Kerr (1974a) and Smith \& Vikki (1978) suggested that the data indicate two locus CSD. Multiple mating could also play a role. Single-locus CSD seems most likely but the current data cannot rule out a multilocus model.

Solenopsis invicta. Diploid males were reported in the fire ant, Solenopsis invicta by Hung et al. (1972). These were subsequently shown to be both sterile (Hung et al., 1974) and biparental (Hung \& Vinson, 1976). More recently, there have been several studies of the interaction between diploid male production and colony structure and survival but sex determination has not been specifically addressed.

Ross \& Fletcher (1986) reported that 90-95 per cent of males in mature, polygyne (multiqueen) colonies are diploid. Large numbers of diploid males suggest single rather than multilocus CSD but the more informative ratio of diploid males to females is unknown. An explicit test of single-locus CSD would be valuable since the model has yet to be confirmed for any ant species, despite many reports of diploid males in ants (Table 1).

Bombus atratus. Garófalo (1973) analysed the offspring from a mother/son cross of the neotropical bee, Bombus atratus and hypothesized the existence of a two-locus system in which only the double heterozygotes are female. Crozier (1977) criticized this hypothesis on two grounds. First, such a system would be highly maladaptive, leading to more diploid males than single-locus CSD. Secondly, while Garófalo showed cytologically that 10 males were diploid, he also assumed that the 17 other (unkaryotyped) males were all diploid. This ignores the likely production of some haploid males and prevents the data from discriminating between one and two-locus models (Crozier, 1977). There are similar problems with progeny data from a virgin triploid female studied by Garófalo \& Kerr (1975). At present, it appears that one or two-locus CSD operates in $B$. atratus but better data are needed.
Trigona quadrangula. Tarelho (1973) found a ratio of three females to one diploid male in a single brood comb of this species. Kerr (1974a) and Moritz (1986) cited these data as evidence of two-locus CSD but this conclusion is unwarranted since it is not known whether the queen was inseminated by one or more males.

Pteromalus puparum. Whiting (1940) re-examined data on the sex-linkage of an eye colour mutant in the parasitoid wasp Pteromalus puparum (Chalcidoidea), collected by Dozorceva (1936). Whilst the experiments were not designed to test Whiting's (1943) model of single-locus CSD, the patterns of sex-linkage observed were similar to those resulting from diploid male production in Bracon hebetor. Further studies on this species would be most interesting since data from several other chalcidoid wasps contradict CSD (see sections 5 and 6 ).

\section{Other species with diploid males}

Diploid males have now been detected in 33 species of Hymenoptera (Table 1), a considerable increase on the 12 reported by Page \& Metcalf (1982). These cases suggest strongly that genic balance does not apply and support the notion that CSD is widespread. However, the simple detection of a diploid male does not demonstrate single-locus CSD since the occasional diploid males that occur in Nasonia vitripennis (Whiting, 1960) and Diplolepis rosae (Still \& Davring, 1980) are uniparental and experiments on both species contradict CSD. Male heterozygosity or size dimorphism (e.g. in sawflies) is likely to be the first indication of diploid males but further investigation is required to provide convincing evidence since male dimorphism is quite common in Hymenoptera and haploid males with tandem gene duplications can also appear heterozygous (Hung, 1984).

\section{The molecular basis of CSD}

CSD models describe a primary sex-determining signal and could be consistent with a variety of molecular pathways. Despite the fact that the Bracon sex locus mapped as a point on the linkage map, Whiting (1943, $1945)$ argued that it was a polygenic chromosome segment and that "genes governing secondary as well as primary sex differences must lie in this chromosome segment, the genes for male traits being recessive". This assertion appears to have no observational basis and implicitly equates the genes responsible for sex determination with those that cause sexual differentiation, as in genic balance models. However, recent 
molecular studies in Drosophila and Caenorhabditis (reviewed in Hodgkin, 1990) have shown that sex is determined by a few major genes that are distinct from (and regulate) those that cause sexual differentiation. Consequently, there is currently no reason to believe that the hymenopteran sex locus is not a single gene.

Crozier (1971) hypothesized that the sex locus might produce a molecule that is only active as a heteropolymer formed with the peptide of a different sex allele. Alternatively, each sex allele could produce activator mRNA defective in one or more cistrons, which are compensated for in heterozygotes but not in homozygotes (Kerr, 1975). There is some empirical evidence that feminization does result from the action of the diffusable products of different sex alleles. In $B$. hebetor (Whiting et al., 1934) and A. mellifera (Rothenbuhler, 1957), the borders between tissues of different haplotypes were found to be feminized, although a subsequent experiment by Drescher \& Rothenbuhler (1964) failed to find evidence of feminization.

Periquet et al. (1993) suggested that multilocus CSD might evolve from single-locus CSD by tandem duplication of the sex locus, followed by dispersal of the repeated genes to other chromosomes. If different allelic products lead to femaleness, the subsequent evolution of a multiple locus system would require that the female-producing reaction is somehow restricted within loci (Bull, 1981).

\section{Evidence against CSD}

Many parasitoids habitually inbreed and sib-mating may be obligate or close to obligate in several species. Habitual inbreeding rapidly leads to high levels of diploid males under single-locus CSD and led Crozier
(1971) to propose multilocus CSD for such species. Crozier (1971) argued that diploid male production would remain low as long as occasional outcrosses occurred between inbreeding lines. The multilocus CSD model is more difficult to exclude since there is no a priori specification of the number of loci involved, which determines the number of generations in inbreeding required to generate detectable diploid male production (Cook, 1993). I am aware of only two studies that have explicitly tested the multilocus model, both in inbreeding species. Skinner \& Werren (1980) sib-mated Nasonia vitripennis (Chalcidoidea: Pteromalidae) for six generations and Cook (1993) sib-mated Goniozus nephantidis (Chrysidoidea: Bethylidae) for 22 generations. Neither study found changes in sex ratio or mortality and they were able to exclude models involving up to six and 15 loci, respectively.

Inbreeding over several generations has failed to produce male-biased sex ratios in several parasitoid species that naturally sib-mate (Table 2) and singlelocus CSD can be ruled out for these cases. However, with the exception of the studies of Skinner \& Werren (1980) and Cook (1993), the experiments were not designed to test multilocus CSD. Multilocus CSD cannot be completely ruled out in the other cases because the studies are insufficient tests of the model for one or more of the following reasons: few generations of inbreeding, absence of mortality analysis and the incorporation of occasional outcrosses. Despite these caveats, CSD is unlikely to apply to the species in Table 2 , which are all endogamous. Furthermore, most of the species in Table 2 belong to the Chalcidoidea and there is considerable experimental evidence against CSD for this superfamily.

Table 2 Parasitoid species in which the sex ratio has not increased with inbreeding. Single locus CSD can be ruled out for these species but multilocus CSD has been tested rigorously in only two cases (see text)

\begin{tabular}{|c|c|c|}
\hline Taxon & Species & Reference \\
\hline \multicolumn{3}{|l|}{ Parasitica } \\
\hline Chalcidoidea & Cothanapsis boulardi & Biêmont \& Bouletreau (1980) \\
\hline Chalcidoidea & Dinarmus vagabundus & Rojas-Rousse et al.(1988) \\
\hline Chalcidoidea & Melittobia chalybii & Schmieder (1938) \\
\hline Chalcidoidea & M. 'sp. C' & Schmieder \& Whiting (1947) \\
\hline Chalcidoidea & Muscidfurax raptor & Legner (1979), Fabritius (1984) \\
\hline Chalcidoidea & M. zaraptor & Legner $(1979)$ \\
\hline Chalcidoidea & Nasonia vitripennis & Skinner \& Werren (1980) \\
\hline Cynipoidea & Leptopilina heterotoma & Hey \& Gargiulo (1985) \\
\hline \multicolumn{3}{|l|}{ Aculeata } \\
\hline Chrysidoidea & Goniozus nephantidis & $\operatorname{Cook}(1993)$ \\
\hline
\end{tabular}


Aside from inbreeding experiments, there have also been other studies of sex determination in two inbreeding parasitoid species: Telenomus fariai (Proctotrupoidea: Scelionidae) and Nasonia vitripennis (Chalcidoidea: Pteromalidae). Dreyfus \& Breuer (1944) inferred a bizarre cytogenetic mechanism in $T$. fariai based on their cytological preparations. Their scheme involved sex chromosomes and differential maturation of $\mathrm{X}$ and Y-bearing eggs. However, they were unable to demonstrate the full process and other reports of sex chromosomes in Hymenoptera have not withstood repeated scrutiny (White, 1973).

Diploid males have been detected in $N$. vitripennis but are uniparental and highly fertile (Whiting, 1960). They produce triploid or tetraploid daughters when mated to diploid or triploid females respectively (Whiting, 1960). The fertility of triploid females is low but not drastically reduced as in $B$. hebetor. This is a consequence of the lower incidence of aneuploid offspring from $N$. vitripennis triploid females, which may in turn reflect the fact that $N$. vitripennis has five chromosomes per haploid set and B. hebetor has 10 . All the offspring of triploid females are male (either haploid or diploid).

The above evidence does not support CSD or genic balance. It is, however, consistent with a model of environmental sex determination, with fertilization as the cue, regardless of ploidy level. However, Friedler \& Ray (1951) showed that individuals arising from fertilized eggs with maternal genes inactivated by irradiation are male. Thus fertilization per se does not determine sex.

Both haploid and diploid intersexes have been found in N. vitripennis (Whiting, 1967). However, these have not shed light on the primary sex-determining signal and are unlikely to help discriminate between models since they may often be attributable to mutations at loci that are normally sex-limited.

There is a need for new hypotheses of sex determination in species of Hymenoptera that lack CSD. One possibility is a mechanism that depends upon the balance of nuclear and cytoplasmic products (Crozier, 1977). Female determination in Drosophila melanogaster depends on the presence of a diploid complement of X-chromosome numerator elements and the presence of the maternal product of the $d a$ gene (Cline, 1988, 1989). A related system for inbreeding Hymenoptera could involve a maternal product that permits male development in haploids but is outweighed by a diploid complement of female-determining genes (Cook, 1993). Such a system could be derived simply from CSD if CSD itself depends on the balance between a maternal product and offspring genotype, with heterozygosity at the sex locus defining the gender threshold. The molecular basis of CSD is unknown but a loss of CSD could be a simple genetic event. For example, if the role of sex locus heterozygosity is activation of female-determiners, any regulatory change that decouples sex locus heterozygosity and female gene expression might lead to loss of CSD.

\section{Thelytoky}

Thelytokous races, consisting entirely of females that arise from unfertilized eggs, occur sporadically in the Hymenoptera, and are most prevalent in the Parasitica (White, 1973; Crozier, 1975; Luck et al., 1992). Thelytokous races can persist under CSD as long as one or more sex loci remain heterozygous (Smith, 1941; Whiting, 1945). Consequently, the cytogenetic mechanism must be known to evaluate a particular case. Apomictic mechanisms do not involve crossingover and lead to offspring that are genetically identical to the mother. This is clearly consistent with CSD but apomixis appears to be rare in Hymenoptera. Apomixis has, however, been reported in one sawfly Strongylogaster macula (Peacock \& Sanderson, 1939) and in the honeybee (Tucker, 1958).

In most thelytokous Hymenoptera normal meiosis occurs and diploidy is restored by fusion of meiotic products (Crozier, 1975; Suomalainen et al., 1987). However, the different forms of automixis vary in their consistency with sex determination by CSD. Persistent thelytoky occurs in the cape honeybee Apis mellifera capensis. Following normal meiosis, diploidy is restored by central (non-sister) fusion (Verma \& Ruttner, 1981). Genomic homozygosity is increased by central fusion but loci closely linked to the centromere may retain heterozygosity (Suomalainen et al., 1987). It thus seems likely that the sex locus is located close to the centromere. An automictic mechanism that is genetically equivalent to central fusion occurs in the thelytokous parasitoid Venturia canescens (Ichneumonidae). Speicher et al. (1965) found one male during their experiments, a diploid son of an X-rayed mother. By analogy with $A$. m. capenis, CSD could apply to this species and Crozier (1971) argued that the single diploid male probably resulted from inactivation of one sex allele. In another parasitoid Aphytis mytilaspidis (Aphelinidae), diploidy is restored by terminal (sister) fusion (Rössler \& Debach, 1973). This mechanism is less likely to permit persistent thelytoky under CSD since it must rely on regular crossing-over between the centromere and the sex locus. Terminal fusion has also been reported in the diprionid sawfly Pristiphora rufipes (Comrie, 1939). Since two other diprionid sawflies are known to have CSD, it may be 
possible for CSD to underlie thelytoky by terminal fusion.

If diploidy is restored by gamete duplication, complete homozygosity is achieved and diploid males would be produced under CSD. Gamete duplication occurs in Diplolepis rosae (Cynipidae) but the vast majority of offspring are female (Stille \& Dävring, 1980). Occasional diploid males occur but they have one chromosome set totally heterochromatinized, i.e. they are functionally haploid. CSD does not apply here and seems unlikely to apply to cynipid wasps in general, where the mode of reproduction alternates between arrhenotoky-thelytoky or thelytoky-deuterotoky (Askew, 1984). Mechanisms leading to total homozygosity also occur in the parasitoids Muscidifurax uniraptor (Pteromalidae - Legner, 1985) and several Trichogramma spp. (Trichogrammatidae Stouthamer et al., 1993). CSD does not apply in these taxa.

Recent studies have shown that microbes are responsible for thelytoky in several Trichogramma spp. (Stouthamer et al., 1990a, b) and Encarsia formosa (Zchori-Fein et al., 1992). In these races asexuality can be cured (male production resumed) by treatment with high temperatures or antibiotics. In another parasitoid wasp Nasonia vitripennis studies have revealed both male-biasing and female-biasing cytoplasmic elements (Skinner, 1982; Werren et al., 1986; Nur et al., 1988), although the latter do not lead to complete thelytoky. A similar sex ratio distorter has just been reported in Encarsia pergandiella (Hunter et al., 1993) and the fact that many workers have noted temperature effects on parasitoid sex ratios suggests that such elements are likely to be widespread.

Parthenogenesis bacteria and other sex ratio distorters are of relevance to sex determination in two ways. First, they disrupt the normal cytogenetic mechanics and may provide information on sex determination. For example, bacteria cause an endomitotic division, leading to complete homozygosity in Muscidifurax uniraptor (Legner, 1985). Secondly, cytoplasmic elements that bias the offspring sex ratio may lead to curious results in breeding experiments. These could lead to erroneous conclusions if the true cause is not identified.

The distribution of thelytoky amongst different Hymenopteran taxa is poorly understood. Luck et al. (1992) list 270 cases exclusive of the Cynipoidea, whose mode of reproduction is not primarily arrhenotokous. Secondary, thelytoky seems to be most prevalent in the Chalcidoidea and there is considerable evidence that CSD does not apply to arrhenotokous members of this superfamily. However, Luck et al. (1992) also listed 32 of 90 cases of thelytoky from the superfamilies Ichneumonoidea and Tenthredinoidea respectively and experiments on arrhenotokous species from these taxa support single-locus CSD. Thus thelytoky per se is probably not a good indicator of the sex-determining mechanism.

It is possible that thelytokous races arise more often from inbreeding than outbreeding species. Many inbreeding parasitoids lay broods on patchily distributed hosts. In such cases, thelytoky may be favoured over arrhenotoky for two reasons (Cornell, 1988; Hardy, 1992): (i) it removes the problem of producing precise sex ratios and the risk of unmatedness if no males mature in the brood (especially as these conditions also select for female-biased sex ratios); and (ii) it will lead to a rise in the intrinsic rate of increase if thelytokous mothers produce more daughters (see Luck et al., 1992 for a review). Thus there may be stronger selection for a thelytokous mutation in inbreeding populations, which are unlikely to have CSD, resulting in a low incidence of CSD amongst thelytokous races.

\section{Phylogenetic patterns}

The order Hymenoptera is widely accepted as a monophyletic taxon but the internal phylogeny remains controversial. The traditional arrangement comprises two sub-orders (Symphyta and Apocrita) with the Apocrita divided into two infra-orders (Aculeata and Parasitica). These are well-established and biologically useful taxa but may not be an accurate reflection of phylogeny (Gauld \& Bolton, 1988). The composition of the Symphyta varies with respect to whether the Cephoidea (Königsmann, 1977) or the Orussoidea (Rasnitsyn, 1980) are removed and placed as the sister group to the Apocrita. If both are retained, it is not possible to justify the Symphyta with shared, derived characters relative to the Apocrita (Gauld \& Bolton, 1988). The Apocrita are generally considered monophyletic, based on the fusion of the thorax and first abdominal segment, and there is no dispute over the monophyly of the Aculeata. However, the relationships and composition of the Parasitica superfamilies remain problematic with monophyly unlikely (Königsmann, 1978; Gauld \& Bolton, 1988; Rasnitsyn, 1988). Recently, Rasnitsyn (1988) suggested that the parasitoid superfamily Ichneumonoidea is the sister group of the Aculeata. The apparent predominance of CSD in both of these taxa but not in the Chalcidoidea might support this suggestion. However, a recent molecular investigation of hymenopteran phylogeny, using sequence data from mitochondrial 16s rRNA, strongly favoured a clade comprising the Ichneumonoidea and Chalcidoidea, separated from the Aculeata (Derr et al., 
1992). The data set, though of more limited resolution at higher levels, was also consistent with the conventional dichotomies between Symphyta and Apocrita and then Aculeata and Parasitica. Analysis of patterns within the Hymenoptera would be greatly enhanced by better phylogenies. Morphological analyses appear unable to solve many problems but recent work with mtDNA (Derr et al., 1992; Jermiin \& Crozier, in preparation) suggests that molecular data should help to resolve at least some remaining questions.

Information on sex determination is available for only seven of the 18 superfamilies recognized by Gauld \& Bolton (1988). I have assigned the superfamilies into three categories: those with CSD, those without CSD and those for which no data are available (Fig. 1). Some of these assignments are based on very few cases (a single experimental study in both the Cynipoidea and Chrysidoidea) and further data may well alter these tentative conclusions. For example, species with and without CSD may well occur in the same superfamily. However, this has yet to be shown.

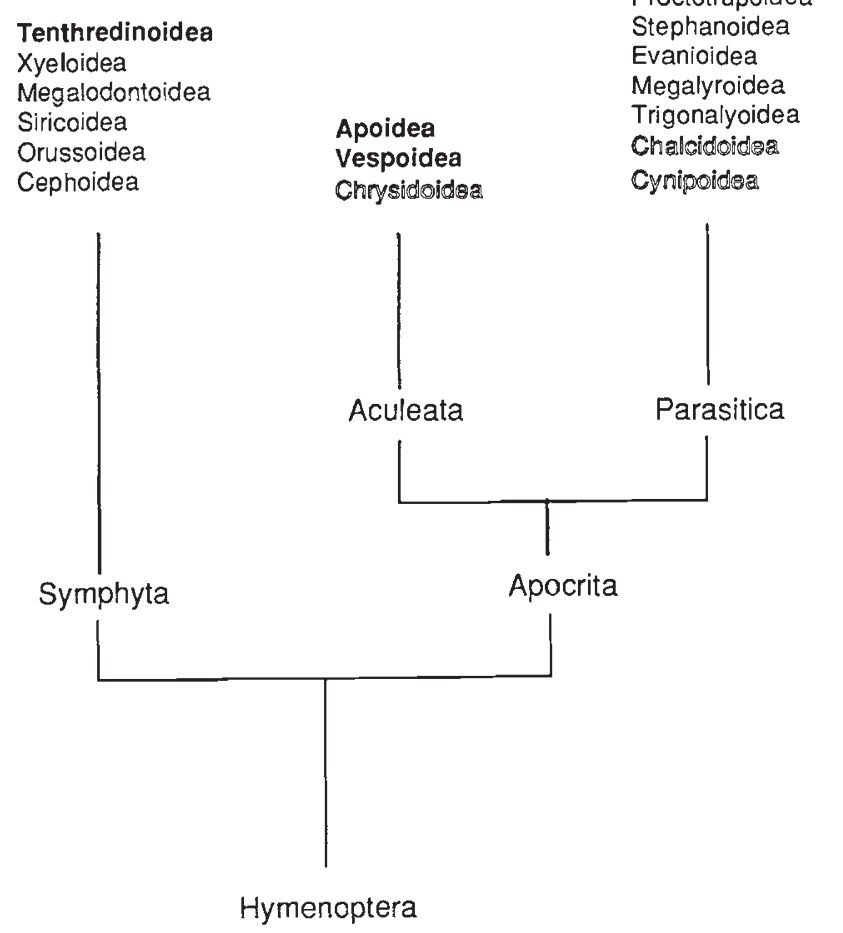

Fig. 1 A phylogenetic perspective of sex determination in the Hymenoptera. All superfamilies recognized by Gauld \& Bolton (1988) are shown. Bold indicates evidence for singlelocus CSD, outline text indicates evidence against CSD and normal type represents no pertinent data. See text for further details.
Single-locus CSD occurs in at least two species from each of the three major branches (Symphyta, Aculeata, Parasitica) of the order Hymenoptera. This suggests that it is either ancestral (Schmieder \& Whiting, 1947; Crozier, 1977) or has evolved repeatedly. The former hypothesis is favoured both by parsimony and by the fact that single-locus CSD, with its inherent genetic load of sterile, diploid males, is unlikely to evolve from any haplodiploid system (such as genic balance) with diploid females (Crozier, 1977; Bull, 1981). Information on sex determination in other Symphytan superfamilies would be particularly useful for the evaluation of this hypothesis.

If single-locus CSD is ancestral to the Hymenoptera, changes in sex determination would be expected in lineages that adopted an inbreeding lifestyle, involving high diploid male production (Schmieder \& Whiting, 1947; Crozier, 1971). All of the species so far shown not to have single-locus CSD are more or less endogamous. There may be no outcrossing at all in Telenomus fariai (Dreyfus \& Breuer, 1944) while the inbreeding level is quite variable in Nasonia vitripennis, depending on the incidence of superparasitism (Werren, 1987). Endogamy is most prevalent in the Parasitica and has probably evolved several times. Different inbreeding taxa may therefore have evolved different mechanisms that avoid diploid male production.

A related problem is the evolutionary origin of single-locus CSD. Arrhenotoky has probably evolved only 8-12 times, once in the common ancestor of modern Hymenoptera (White, 1973; Bull, 1983, p. 149). Paternal genome loss (PGL) and diploidy seem the most likely predecessors of arrhenotoky (Bull, 1983 , p. 150). However, the general co-occurrence of arrhenotoky and PGL may only indicate that they tend to arise from diploidy under similar conditions (Bull, 1981 , p. 150). For arrhenotoky to evolve, viable uniparental males must be produced by the ancestral diplodiploid system. This may well be a major constraint on the evolution of arrhenotoky but has rarely been investigated (Bull, 1983, p. 178). Hartl \& Brown (1970) considered the evolution of arrhenotoky from male heterogamety (XX female, XY male, $\mathrm{X}$ male) and showed that arrhenotoky could become established (and diploid males lost) if both the proportion of unfertilized eggs $(u)$ and the ratio of haploid:diploid male fitness $(w)$ were close to 0.5 . If either $u$ or $w$ remained close to zero, arrhenotoky would not become established. Bull (1981) explored the transition from $\mathrm{ZZ/ZW}$ female heterogamety system to arrhenotoky with single locus CSD. He noted that all known cases of female heterogamety could potentially have systems of sex determination similar to CSD, unless it is shown 
that ZW and WW are the same sex. Conditions for the transition from female heterogamety to arrhenotoky with single locus CSD are similar to those in the Hartl-Brown model and it is critical that $w$ equals or exceeds 0.5 . One difference is that diploid males cannot be totally eliminated.

The models of Hartl \& Brown (1970) and Bull (1981) assume random mating. Inbreeding might facilitate the evolution of arrhenotoky by decreasing the frequency of recessive, deleterious genes (Bull, 1979; Borgia, 1980). However, inbreeding also leads to high diploid male production, which would likely outweigh any advantage due to reduced frequencies of deleterious recessives (Bull, 1981).

\section{Conclusion}

Single-locus CSD is clearly widespread in Hymenoptera but more experiments are needed to delimit its taxonomic distribution. Such experiments will be most valuable if they target the less-studied taxa and should be designed to also test the multilocus model if the single-locus case is not supported (Cook, 1993). Satisfactory analyses of phylogenetic patterns and the polarity of sex determination transitions must await a wider database on sex determination in the Hymenoptera but also require a better understanding of the relationships of the various superfamilies.

Further understanding of the genetic mechanism of single-locus CSD will probably come from molecular studies, as was the case for Drosophila and Caenorhabditis. Such studies would be particularly interesting since CSD is the only documented sex-determining mechanism that involves sex factors (in this case alleles) that do not have particular sex tendencies (Bull, 1983). Aside from its intrinsic interest, CSD has wider importance because Hymenoptera are key organisms for the study of evolutionary problems such as sex allocation and the evolution of sociality, and correct interpretation of behavioural phenomena may depend on recognition of CSD (Ratnieks, 1990; Cook, in preparation). Diploid male production influences population ecology (e.g. Ross \& Fletcher, 1986) and is an important factor in the design of honeybee rearing strategies (Woyke, 1986). It also appears to influence the success of biological control attempts using parasitoids (Stouthamer et al., 1992).

\section{Acknowledgements}

My research is supported by a Royal Commission for the Exhibition of 1851 Postdoctoral Fellowship. I am grateful to Ross Crozier, Greg Hampikian, Ian Hardy,
Ary Hoffman, Sally Power, Jack Werren and an anonymous referee for comments on the manuscript.

\section{References}

ASKEw, R.R. 1984. The biology of gall wasps. In: Ananthakrishnan, T. N. (ed.) Biology of Gall Insects, Edward Arnold, London, pp. 223-271.

BAKER, B. S. AND BELoTTE, J. M. 1983. Sex determination in Drosophila melanogaster. Ann. Rev. Genet., 17, 345-393.

BIEMONT, C. AND BOULETREAU, M. 1980. Hybridisation and inbreeding effects on genome coadaptation in a haplodiploid hymenopteran: Cothonapsis boulardi (Eucoilidae). Experientia, 36, 45-47.

BORGIA, G. 1980. Evolution of Haplodiploidy: Models for Inbred and Outbred Systems. Theor. Pop. Biol., 17, 103-128.

Bostian, C. H. 1934. Biparental males and biparental ratios in Habrobracon. Biol. Bull., 66, 166-181.

BRIDGES, C. B. 1916 . Non-disjunction as proof of the chromosome theory of heredity. Genetics, 1, 1-52 and 107-163.

BRIDGES, C. B. 1921. Triploid intersexes in Drosophila. Science, 54, 252-254.

BRIDGES, C. B. 1922. The origin of variations in sexual and sexlimited characters. Am. Nat., 56, 51-63.

BRIDGES, C. B. 1939. Cytological and genetic basis of sex. In: Allen, C. et al. (eds.) Sex and Internal Secretions, 2nd edn, Williams \& Wilkins Co., Baltimore, pp. 15-63.

BULL, J. J. 1979. An advantage for the evolution of male haploidy and systems with similar genetic transmission. Heredity, 43, 361-381.

BULL, J. J. 1981. Coevolution of haplodiploidy and sex determination in the Hymenoptera. Evolution, 35, 568-580.

BULL, J. J. 1983, Evolution of Sex Determining Mechanisms. Benjamin/Cummings, Menlo Park, California.

CAmargo, C. A. 1979. Sex determination in bees. XI, Production of diploid males and sex determination in Melipona quadrifasciata (Hymenoptera, Apidae). J. Apic. Res., 18, 77-84.

Chaud-netto, J. 1975. Sex determination in bees II. Additivity of maleness genes in Apis mellifera. Genetics, 79, 213-217.

ClARK, A. M. AND RUBIN, M. A. 1961. The modification by $X$-radiation of the life span of haploids and diploids of the wasp, Habrobracon sp. Radiation Res., 15, 244-253.

CLINE, T. W. 1988. Evidence that sisterless-a and sisterless-b are two of several discrete 'numerator elements' of the $\mathrm{X} / \mathrm{A}$ sex determination signal in Drosophila that switch $s x l$ between two alternative stable expression states. Genetics, 119, 829-862.

CLINE, T. w. 1989. The affairs of daughterless and the promiscuity of developmental regulators. Cell, 59, 231-234.

COMRIE, L. C. 1939. Biological and cytological observations on tenthredinid parthenogenesis. Nature, 142, 877.

COOK, J. M. 1993. Empirical tests of sex determination in Goniozus nephantidis (Hymenoptera: Bethylidae). Heredity, 71, 130-137. 
CORNELL, H. V. 1988. Solitary and gregarious brooding, sex ratios and the incidence of thelytoky in the parasitic Hymenoptera. Am. Midland Nat., 119, 63-70.

CROzIER, R. H. 1971. Heterozygosity and sex determination in haplodiploidy. Am. Nat., 105, 399-412.

CRozier, R. H. 1975. Hymenoptera.. In: John, B. (ed.) Animal Cytogenetics 3: Insecta 7. Gebr., Borntraeger, Berlin, pp. $1-95$.

CROZIER, R. H. 1977. Evolutionary genetics of the Hymenoptera. Annu. Rev. Entomol., 22, 263-288.

CUNHA, A. B. AND KERR, w. E. 1957. A genetical theory to explain sex determination by arrhenotokous parthenogenesis. Forma et Functio. 1, 33-36.

DERR, J. N., DAVIS, S. K., WOOLLEY, J. B. AND WHARTON, R. A. 1992. Variation and phylogenetic utlity of the large ribosomal subunit of mitochondrial DNA from the insect order Hymenoptera. Mol. Phylog. Evol., 1, 136-147.

Dozorceva, R. L. 1936. Sex-limited heredity in Pteromalus puparum. C.R. (Doklady) de l'Academie des Sciences de l'URSS, III (XII), 3, 335-338. Cited in Whiting (1940).

DRESCHER, w. AND ROTHENBUHLER, w. C. 1964. Sex determination in the honeybee. J. Hered., 55, 91-96.

DREYFUS, A. AND BREUER, M. E. 1944. Chromosomes and sex determination in the parasitic hymenopteran Telenomus fariai Lima. Genetics, 29, 75-82.

FABRITIUS, k. 1984. Untersuchungen uber eine Inzucht von Muscidifurax raptor unter Labordebingungen. Entomol. Genet., 9, 237-241.

FISCHER, K. 1987. Karyotypuntersuchungen an selbstandigen und sozialparatischen ameisen des tribus Leptothoracini (Hymenoptera: Formicidae) im hinblik auf ihre verwandtschaftesbeziehungen. Dissertation FBTH, Darmstadt.

FRIEDLER, C. AND RAY, O. T. 1951. Androgenesis in the wasp Mormoniella. Anat. Rec., 111, 475.

GAROFALO, C. A. 1973. Occurrence of diploid drones in a Neotropical bumblebee. Experientia, 29, 726-727.

GAROFALO, C. A. AND KERR, w. E. 1975. Sex determination in bees I. Balance between maleness and femaleness genes in Bombus atratus Franklin. Genetica, 45, 203-209.

GAUld, I. AND Bolton, B. 1988. The Hymenoptera. Oxford University Press \& British Museum (Natural History), Oxford \& London.

GROSCH, D. S. 1945. The relation of cell size and organ size to mortality in Habrobracon. Growth, 9, 1-17.

hamilton, w. D. 1967. Extraordinary sex ratios. Science, 156, 477-488.

HARDY, I. C. W. 1992. Non-binomial sex allocation and brood sex ratios in the parasitoid Hymenoptera. Oikos, 65, 143-158.

HARTL, D. L. AND BROWN, S. w. 1970. The origin of male haploid genetic systems and their expected sex ratio. Theor. Pop. Biol., 1, 165-190.

HEDDERWICK, M. P., El AGOZE, M., GARAUd, P. AND PERIQUeT, G. 1985. Mise en evidence de males heterozygotes chez l'hymenoptère Diadromus pulchellus. Genet. Sel. Evolut., 17, 303-310.

HEY, J. AND GARGIULO, M. K. 1985. Sex-ratio changes in Leptopilina heterotoma in response to inbreeding. J. Hered., 76, 209-211.
Hodgkin, J. 1990. Sex determination compared in Drosophila and Caenorhabditis. Nature, 344, 721-728.

Hoshiba, H., OKADA, I. AND KusAnagi, A. 1981. The diploid drone of Apis cerana japonica and its chromosomes. $J$. Apic. Res., 20, 143-147.

HUNG, A. C. F. 1984. Tandem gene duplication and fixed heterozygosity in the parasitic wasp Trichogramma marylandense. Experientia, 41, 508-509.

HUNG, A. C. F., IMAI, H. T. AND KUBOTA, M. 1972. The chromosomes of nine ant species from Taiwan, Republic of China, Annal. Entomol. Soc. Am., 65, 1023-1025.

HUNG, A. C. F. AND VINSON, S. B. 1976. Biochemical evidence for queen monogamy and sterile male diploidy in the fire ant, Solenopsis invicta. Isozyme Bull., 9, 42.

HUNG, A. C. F., VinSON, S. B. AND SUMMERLin, J. W. 1974. Male sterility in the imported red fire ant, Solenopsis invicta. Annal. Entomol. Soc. Am., 67, 909-912.

IMAI, H. T. AND yoshidA, T. H. 1968. Polyploid cells observed in male and queen ants of Aphaenogaster osimensis. Ann. Rep. Natl. Inst. Genet. (Japan), 16, 54.

HUNTER, M. S., NUR, U. AND WERREN, J. H. 1993. Origin of males by genome loss in an autoparasitoid wasp. Heredity, $\mathbf{7 0}$, $162-171$.

KERR, w. E. 1974a. Advances in cytology and genetics of bees. Annu. Rev. Entomol., 19, 253-268.

KERR, w. E. 1974b. Sex determination in bees. III. Caste determination and genetic control in Melipona. Insectes Soc., 21, 357-367.

KERR, W. E. 1975. Evolution of the population structure in bees. Genetics, 79, 73-84.

KERR, W. E. 1987. Sex determination in bees. XXI. Number of XO-heteroalleles in a natural population of Melipona compressipes fasciculata (Apidae). Insectes Soc., 34, 274-279.

KERR, W. E. AND NEILSEN, R. A. 1967. Sex determination in bees (Apiinae). J. Apic. Res., 6, 3-9.

KÖNIGSMANN, E. 1977. Das phylogenetische system de Hymenoptera. Teil 2: 'Symphyta'. Dtsch. Entomol. Z., 24, $1-40$.

KÖNIGSMANN, E. 1978. Das phylogenetische system der Hymenoptera. Teil 3: 'Terebrantes' (Unterordnung Apocrita). Dtsch. Entomol. Z, 25, 1-55.

KUKUK, P. F. AND MAY, в. 1990. Diploid males in a primitively eusocial bee, Lasioglossum (Dialictus) zephyrum (Hymenoptera: Halictidae). Evolution, 44, 1522-1528.

LAIDLAW, H. H., GOMES, F. P. AND KERR, W. E. 1956. Estimation of the number of lethal alleles in a panmictic population of Apis mellifera L. Genetics, 41, 179-188.

LEGNER, E. F. 1979. Prolonged culture and inbreeding effects on reproductive rates of two pteromalid parasites of muscoid flies. Ann. Entomol. Soc. Am., 72, 114-118.

LEGNER, E. F. 1985. Effects of scheduled high temperature on male production in thelytokous Muscidifurax uniraptor (Hymenoptera: Pteromalidae). Can. Entomol., 117, 383-389.

LOISELLE, R., FRANCOEUR, A., FISCHER, K. AND BUSCHINGER, A. 1990. Variations and taxonomic significance of the chromosome number in the Nearctic species of the genus 
Leptothorax (S.S.) (Formicidae: Hymenoptera). Caryologia, 43, 321-334.

LUCK, R., STOUTHAMER, R. AND NUNNEY, L. E. 1992. Sex determination and sex ratio patterns in parasitic Hymenoptera. In: Wrensch, D. L. \& Ebbert, M. A. (eds) Evolution and Diversity of Sex Ratios in Haplodiploid Insects and Mites, pp. 442-476.

MACBRIDE, D. H. 1946. Failure of sperm of Habrobracon diploid males to penetrate the eggs. Genetics, 31, 224.

MACKENSEN, o. 1951. Viability and sex determination in the honey bee (Apis mellifera). Genetics, 36, 500-509.

MADI, J. A. AND HERMAN, R. K. 1979. Polyploids and sex determination in Caenorhabditis elegans. Genetics, 93, 393-402.

MORITZ, R. F. A. 1986. Genetics of bees other than Apis melliera. In: Rinderer, T. E. (ed.) Bee Genetics and Breeding, Academic Press, Orlando, Florida, pp. 121-154.

MUELLER, U. 1993. DNA fingerprinting reveals mating frequency, diploid males, worker reproduction and intraspecific nest parasitism in a primitively eusocial bee. Chapter 4 of Haplodiploidy and the evolution of faculative sex ratios in a primitively eusocial bee, $\mathrm{Ph}$. D. Thesis, Cornell University.

MULLER, H. J. 1932. Some genetic aspects of sex. Am. Nat., 66, $118-138$.

NAITO, T. AND SUZUKI, H. 1991. Sex determination in the sawfly Athalia rosae ruficornis: occurrence of triploid males. $J$. Heredity, 82, 101-104.

NUR, U., WERREN, J. H., EICKBUSH, D. G., BURKE, W. D. AND EICKBUSH, T. H. 1988. A "selfish" B chromosome that enhances its transmission by eliminating the paternal genome. Science, 240, 512-514.

oHNo, s. 1979. Major Sex-Determining Genes. SpringerVerlag, Berlin.

PARKER, L. AND OWEN, R. E. 1990. Allozyme variation, linkage disequilibrium and diploid male production of a primitively social bee Augochlorella striata (Hymenoptera; Halictidae). Heredity, 65, 241-248.

PAGE, R. E. AND METCALF, R. A. 1982. Multiple mating, sperm utilization and social evoluition. Am. Nat., 119, 263-281.

PAMILO, P. AND ROSENGREN, R. 1984. Evolution of nesting strategies in ants. Genetic evidence from different population types of Formica ants. Biol. J. Linn. Soc., 21, 331-348.

PEACOCK, A. D. AND SANDERSON, A. R. 1939. The cytology of the thelytokous sawfly Thrinax macula. Trans. Roy. Soc. Edinb., 59, 647.

PEARSON, B. 1983. Hybridisation between the ant species Lasius niger and Lasius alienus: The genetic evidence. Insectes Soc., 30, 402-411.

PERIQUET, G., HEDDERWICK, M. P., EL AGOZE, M. AND POIRIE, M. 1993. Sex determination in the Hymenoptera Diadromus pulchellus (Ichneumonidae): validation of the one-locus multi-allele model. Heredity, 70, 420-427.

PETTERS, R. M. AND METTUS, R. v. 1980. Decreased diploid viability in the parasitoid wasp, Bracon hebetor. J. Hered., 71, 353-356.

QUELLER, D. C., STRASSMANN, J. E. AND hUGHES, C. R. 1992. Genetic relatedness and population structure in primi- tively eusocial wasps in the genus Mischocyttarus $J$. Hymenoptera Res., 1, 81-89.

RASNITSYN, A. P. 1980. Origin and evolution of Hymenoptera. Tr. Paleontol. Inst., 174, 1-190.

RASNITSYN, A. P. 1988. An outline of the evolution of hymenopterous insects. Orient. Insects, 22, 115-145.

RATNIEKS, F. L. w. 1990. The evolution of polyandry by queens in social Hymenoptera: the significance of the timing of removal of diploid males. Behav. Ecol. Sociobiol., 26, 343-348.

ROJAS-ROUSSE, D., ESLAMI, J. AND PERIQUET, G. 1988. Reproductive strategy of Dinarmus vagabundus: real sex ratio, sequence of emitting diploid and haploid eggs and effects of inbreeding on progeny. J. Appl. Entomol., 106, $276-285$.

Ross, K. G. AND FLETCHER, D. J. C. 1986. Diploid male production - a significant colony mortality factor in the fire ant, Solenopsis invicta. Behav. Ecol. Sociobiol., 19, 283-291.

RÖSSLER, Y. AND DEBACH, P. 1973. Genetic variability in the thelytokous form of Aphytis mytilaspidis (Le Baron) (Hymenoptera: Aphelinidae). Hilgardia, 42, 149-175.

ROTHENBUHLER, w. C. 1957. Diploid male tissue as new evidence on sex determination in honeybees. J. Hered., 48, 160-168.

SCHMIEDER, R. G. 1938. The sex ratio in Melittobia chalybii Ashmead, gametogenesis and cleavage in females and haploid males (Hymenoptera: Chalcidoidea). Biol. Bull., 74, 256-266.

SCHMIEDER, R. G. AND WHITING, P. W. 1947. Reproductive economy in the chalcidoid wasp Melittobia. Genetics, 32, 29-37.

SKINNER, S. W. 1982. Maternally inherited sex ratio in the parasitic wasp Nasonia vitripennis. Science, 215, 1133-1134.

SKINNER, S. W. AND WERREN, J. H. 1980. The genetics of sex determination in Nasonia vitripennis. Genetics, 94, s98.

SLOBODCHIKOFF, C. N. AND DALY, H. V. 1971. Systematic and evolutional implications of parthenogenesis in the Hymenoptera. Am. Zool., 11, 273-282.

SMITH, S. G. 1941. A new form of the spruce sawfly identified by means of its cytology and parthenogenesis. Sci. Agric., 21, 245-305.

SMITH, S. G. AND WALLACE, D. R. 1971. Allelic sex determination in a lower hymenopteran, Neodiprion nigroscutum Midd. Can. J. Genet. Cytol., 13, 617-621.

SMITH, S. G. AND VIKKI, N. 1978. Coleoptera. In: John, B. (ed.) Animal Cytogenetics 3: Insecta 7. Gebr., Borntraeger, Berlin.

SNELL, G. D. 1935. The determination of sex in Habrobracon. Proc. Natl. Acad. Sci. U.S.A., 21, 446-453.

SPEICHER, B. R. AND SPEICHER, K. G. 1940. The occurrence of diploid males in Habrobracon brevicornis. Am. Nat., 74, 379-382.

SPEICHER, B. R., SPEICHER, K. G. AND ROBERTS, F. L. 1965. Genetic segregation in the unisexual wasp Devorgilla. Genetics, $\mathbf{5 2}$, 1035-1041.

STEINER, W. W. M. AND TEIG, D. A. 1989. Microplitis croceipes: genetic characterisation and developing insecticide resistant biotypes. Southwest. Entomol., 12, 71-87. 
STILlE, B. AND DÄVRING, L. 1980. Meiosis and reproductive strategies in the parthenogenetic gall wasp Diplolepis rosea. Hereditas, 92, 353-362.

STOUTHAMER, R., LUCK, R. F. AND HAMILTON, w. D. 1990a. Antibiotics cause parthenogenetic Trichogramma (Hymenoptera: Trichogrammatidae) to revert to sex. Proc. Natl. Acad.Sci., U.S.A., 87, 2424-2427.

STOUTHAMER, R., PINTO, J. D., PLATNER, G. R. AND LUCK, R. F. 1990 b. Taxonomic status of thelytokous species of Trichogramma (Hymenoptera: Trichogrammatidae). Ann. Entomol. Soc. Am., 83, 475-481.

STOUTHAMER, R., LUCK, R. F. AND WERREN, J. H. 1992. Genetics of sex determination and the improvement of biological control using parasitoids. Ann. Entomol. Soc. Am., 21, 427-435.

STOUTHAMER, R., BREEUER, J. A. J., LUCK, R. F. AND WERREN, J. H. 1993. Molecular identification of parthenogenesis associated microorganisms. Nature, in press.

Sturtevant, A. H. 1921. Genetical studies on Drosophila simulans. III. Autosomal genes. General discussion. Genetics, 6, 179-207.

SUOMALEINEN, E., SAURA, A. AND LOKKI, J. 1987. Cytology and Evolution in Parthenogenesis, CRC, Boca Raton, Florida.

TARELHo, Z. F. S. 1973. Contribuicae ao estudo citogenetico dos Apoidea. Ph. D. Thesis, University of Sao Paulo, Brasil.

TORVIK-GREB, M. M. 1935. The chromosomes of Habrobracon. Biol. Bull., 68, 125-34.

TUCKER, K. w. 1958. Apomictic parthenogenesis in the honey bee. Genetics, 43, 299-316.

UNRUH, T. R., GONZALEZ, D. AND GORDH, G. 1984. Electrophoretic studies on parasitic Hymenoptera and implications for biological control. Proc. XVIIth Int. Congr. Entomol., 705.

VERMA, S. AND RUTNER, F. 1981. Cytologische analyse der thelytoken parthenogenesis bei der kapbiene (Apis mellifera capensis Escholtz). Apidologie, 12, 88-89.

WARD, P. S. 1980. Genetic variation and the population differentiation of the Rhytidoponera impressa group, a species complex of ponerine ants. Evolution, 34, 1060-1076.

WERREN, J. H. 1987. Labile sex ratios in bees and wasps. Bioscience, 37, 498-506.

WERREN, J. H., SKINNER, S. W. AND HUGER, A. M. 1986. Male-killing bacteria in a parasitic wasp. Science, 231, 990-992.

white, M. J. D. 1973. Animal Cytology and Evolution. Cambridge University Press, Cambridge.
Whiting, A. R. 1961. Genetics of Habrobracon. Adv. Genet., 10, 333-406.

WHITING, A. R. 1976. The biology of the parasitic wasp Mormoniella vitripennis. Q. Rev. Biol., 43, 333-406.

WHITING, P. W. 1939. Sex determination and reproductive economy in Habrobracon. Genetics, 24, 110-111.

whiting, P. w. 1940. Sex-linkage in Pteromalus. Am. Nat., 64, $377-379$

Whiting, P. w. 1943. Multiple alleles in complementary sex determination of Habrobracon. Genetics, 28, 365-382.

WHITING, P. w. 1945 . The evolution of male haploidy. $Q$. Rev. Biol., 20, 231-260.

WHITING, P. w. 1947. Some experiments with Melittobia and other wasps. J. Hered., 38, 11-20.

Whiting, P. w. 1960. Polyploidy in Mormoniella. Genetics, 45, 949-970.

WHITING, P. W., GREB, R. J. AND SPEICHER, B. R. 1934. A new type of sex intergrade. Biol. Bull., 66, 152-165.

WHITING, P. W. AND WHITING, A. R. 1925. Diploid males from fertilised eggs in Hymenoptera. Science, 62, 437-438.

wOYKE, J. 1962. The hatchability of 'lethal' eggs in a two sex allele fraternity of the honeybee. J. Apic. Res., 4, 6-13.

wOYKE, J. 1963. What happens to the diploid drone larvae in a honeybee colony. J. Apic. Res., 2, 73-75.

WOYKE, J. 1965. Genetic proof of the origin of diploid drones from fertilised eggs of the honeybee. J. Apic. Res., 4, 7-11.

WOYKE, J. 1974. Genic balance, heterozygosity and inheritance of testis size in diploid drone honeybees. J. Apic. Res., 13, 77-85.

wOYKe, J. 1979. Sex determination of Apis cerana india. J. Apic Res., 18, 122-127.

WOYKE, J. 1980. Genetic background of sexuality in the diploid drone honeybee. J. Apic. Res., 19, 89-95.

wOYKe, J. 1986. Sex Determination. In: Rinderer, T. E. (ed.) Bee Genetics and Breeding. Academic Press, Orlando, Florida.

WOYKE, J. AND KROL-PALUCH, w. 1985. Changes in tissue polyploidization during development of worker, queen, haploid and diploid drone honeybees. J. Apic. Res., 24, 14-224.

ZCHORI-FEIN, E., ROUSH, R. T. \& HUNTER, M. S. 1992. Female production induced by anti-biotic treatment in Encarsia formosa. Experientia, 48, 102-105. 